\title{
First synthesis of the $N(1)$-bulky substituted imidazole 3-oxides and their complexation with hexafluoroacetone hydrate
}

\author{
Grzegorz Mlostoń* and Marcin Jasiński \\ Department of Organic and Applied Chemistry, University of Łódź, Tamka 12, \\ 91-403 Łódź, Poland \\ E-mail: gmloston@uni.lodz.pl
}

Dedicated to Prof. Heinz Heimgartner on the occasion of his $70^{\text {th }}$ birthday

\begin{abstract}
Synthesis of new 2-unsubstituted imidazole 3-oxides bearing bulky substituents at the N(1) atom, based on the condensation of appropriate alkylamines, formaldehyde, and corresponding $\alpha$ (hydroxyimino)ketone, is described. Treatment of imidazole 3-oxides with hexafluoroacetone hydrate (HFAH) yields crystalline 1:1 complexes in nearly quantitative yields. Heating of isolated complexes possessing phenyl ring at the $\mathrm{C}(4)$ atom of imidazole ring, results in their isomerization into imidazol-2-ones in fair yields. The formation of analogous complexes of HFAH with other azole $N$-oxides is also described.
\end{abstract}

Keywords: Imidazole 3-oxides, hexafluoroacetone hydrate, complexation reactions, imidazol-2ones

\section{Introduction}

In a series of our previous papers diverse aspects of the chemistry of 2-unsubstituted imidazole 3-oxides, including their preparation and selected transformations into more complex imidazole derivatives, were described. ${ }^{1-3}$ In general, substituted imidazole 3-oxides are not available via an oxidation procedure; instead, several cyclization/condensation methods leading to the desired $N$ oxides are known. ${ }^{4}$ The reaction of $\alpha$-(hydroxyimino)ketones with formaldimines (typically available as the corresponding trimers, i.e. hexahydro-1,3,5-triazines) under various conditions can be recommended as a method of choice for preparation of 2-unsubstituted imidazole 3oxides. $^{4 a, b}$ Starting with appropriate substrates, diverse imidazole 3-oxides substituted with $\omega$ hydroxyalkyl, ${ }^{2 \mathrm{a}}$ ester, $^{2 \mathrm{~b}}$ or amide ${ }^{2 \mathrm{c}}$ moieties are accessible. Reactions employing $\alpha, \omega$-diamines furnish corresponding bis-imidazole 3-oxides as well. ${ }^{2 a}$ Moreover, in the case of the enantiomerically pure trans-1,2-diaminocyclohexane the stereochemical information at the 
stereogenic centres of isolated bis-imidazoles is preserved. $^{3}$ Similarly, starting with enantiomerically pure amino acid esters, optically active imidazole derivatives were obtained. ${ }^{2 b}$ However, none of the presented methods was applied for the preparation of $N$-bulky substituted imidazole 3-oxides, which after eventual deoxygenation and quaternization with an appropriate alkylating agent could be converted into imidazolium salts, potentially useful for the synthesis of stable, imidazole based, nucleophilic carbenes (NHC). ${ }^{5}$

The 2-unsubstituted imidazole 3-oxides 1 resemble aldonitrones, and thus, they undergo $[2+3]$ cycloaddition reactions with appropriate dipolarophiles. For instance, they react smoothly with cycloaliphatic thioketones, ${ }^{1 \mathrm{a}}$ isocyanates, ${ }^{1 \mathrm{~b}}$ hexafluoropropene, ${ }^{6}$ and dimethyl acetylenedicarboxylate $(\mathrm{DMAD})^{1 \mathrm{~b}}$ yielding imidazoline-2-thiones, 2-aminoimidazoles, 2(fluoroalkyl)imidazoles, and 2-oxobutanoates, respectively. In all these reactions, cascade processes start with [2+3]-cycloaddition step and subsequent re-aromatization of the heterocycle ring results in the formation of a corresponding $\mathrm{C}(2)$-functionalized imidazole derivative.

Recently we reported on reactions of some imidazole 3-oxides of type 1 with electron deficient 2,2-bis(trifluoromethyl)ethylene-1,1-dicarbonitrile (BTF) (Scheme 1). ${ }^{\text {ld }}$ The corresponding malonodinitriles $\mathbf{2}$ and/or already known imidazol-2-ones $\mathbf{3}$ were obtained in different ratios, depending on the solvent used. In the case of 1-benzyl-4,5-diphenyl-3-oxido- $1 \mathrm{H}$ imidazole hydrate (1a, $\mathrm{R}^{1}=\mathrm{CH}_{2} \mathrm{Ph}, \mathrm{R}^{2}=\mathrm{Ph}$ ), the reaction, carried out in methanol, yielded corresponding $\mathbf{2 a}$ accompanied by small amount of complex $\mathbf{4 a}$. The latter, unexpected product, formed after reaction of 1a with in situ generated hexafluoroacetone hydrate (HFAH), was isolated in a trace yield (8\%). The X-ray diffraction analysis proved the structure of $\mathbf{4 a}$ as a centrosymmetric tetramer (2:2 complex) with four hydrogen bonds closing a 12-atom loop (Figure 1).

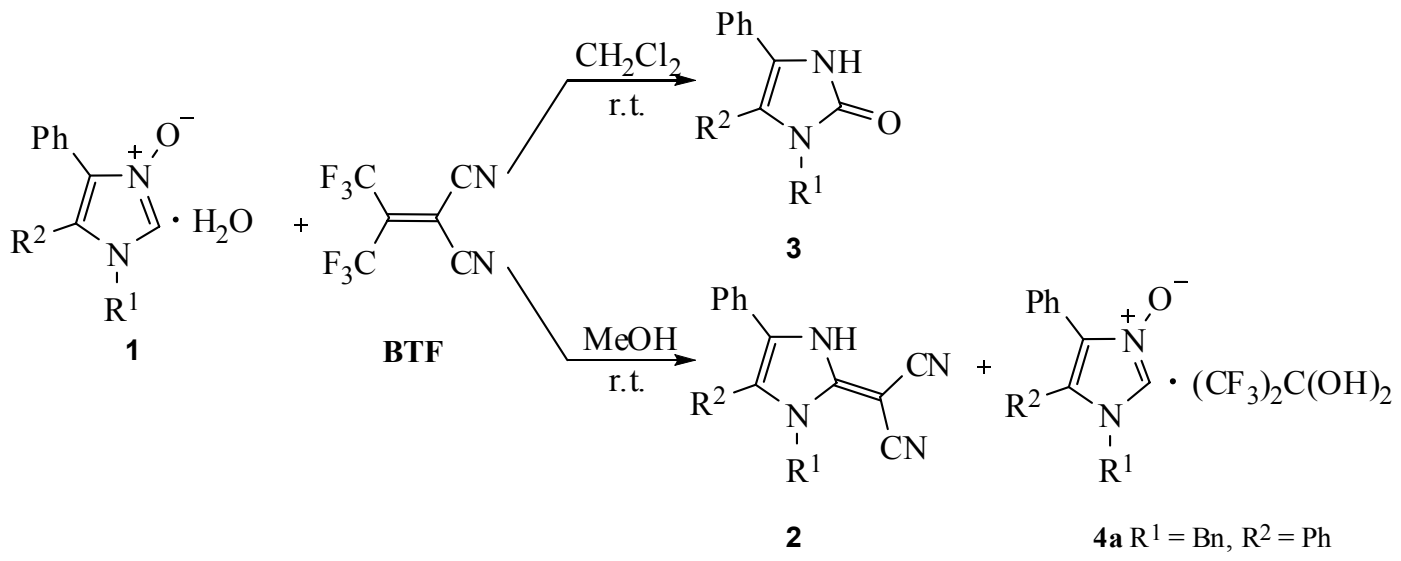

Scheme 1. Reactions of imidazole 3-oxides of type 1 with BTF (ref. ${ }^{1 \mathrm{~d}}$ ). 


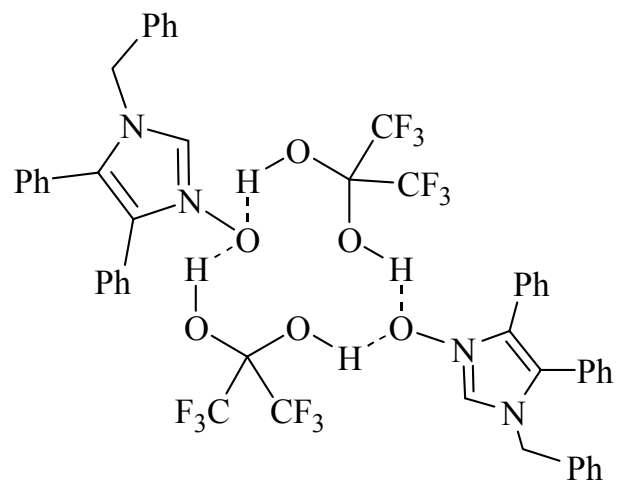

$4 \mathbf{a}$

Figure 1. 'Dimeric' structure of the complex 4a formed from 1-benzyl-4,5-diphenylimidazole 3oxide and hexafluoroacetone hydrate established by means of X-ray diffraction analysis (ref. ${ }^{1 \mathrm{~d}}$ ).

Since the azaaromatic $N$-oxides display a significant nucleophilic and basic character, they react with acidic agents yielding the corresponding salts. For example, some of pyridine $N$ oxides were tested as Lewis bases towards $p$-toluic $\operatorname{acid}^{7 \mathrm{a}}$ and hydroquinone ${ }^{7 \mathrm{~b}}$ to give corresponding 1:1, and 2:1 complexes, respectively. On the other hand, smooth transformation into hydrochlorides is a general and useful method for the isolation/purification of crude imidazole and oxazole $N$-oxides during the workup procedures. ${ }^{2 b, 3 a, 8}$ Similarly, $(+)-(R)-($ tertbutyl)(phenyl)phosphonothioic acid is used as a chiral solvating agent in order to determine the enantiopurity of the in situ formed, corresponding salts of chiral imidazole $N$-oxides. ${ }^{2 b, 3 a}$ However, to the best of our knowledge, a systematic study on the reactions of azaaromatic $N$ oxides with HFAH was not described in literature so far.

The first goal of the present paper was focused on preparation of $N$-bulky substituted imidazole 3-oxides using extremely hindered primary amines such as tert-butylamine and 1aminoadamantane; less hindered isopropylamine was also included for the first time in the study. In extension of the preliminary observation made with 1a a series of analogous imidazole 3oxides complexes with hexafluoroacetone hydrate were prepared and studied with respect to their physico-chemical and chemical properties. For comparison, other heteroaromatic $N$-oxides, derived from diphenylquinoxaline, 1,2,4-triazole and oxazole were also tested in their reactivities towards hexfluoroacetone hydrate.

\section{Results and Discussion}

For the present study, new $N$-bulky substituted imidazole 3-oxides $\mathbf{1 b}$-e were prepared starting with sterically hindered 1-aminoadamantane, tert-butylamine and iso-propylamine, respectively. The amines were converted into formaldimines $\left(\mathrm{R}^{1}=\mathrm{Ad}, t\right.$-Bu) (monomeric forms) or hexahydro-1,3,5-triazine $\left(\mathrm{R}^{1}=i\right.$-Pr) using either paraformaldehyde or aqueous formaldehyde 
solution (formalin) (Scheme 2). ${ }^{9}$ Isolated products were reacted with diacetyl monooxime or benzil monooxime giving the expected imidazole 3-oxides $\mathbf{1 b}$-e in satisfactory yields. Preliminary test experiment was carried out using the most bulky $N$-methylidene-1aminoadamantane and diacetyl monooxime in boiling ethanol, following the general procedure. ${ }^{4 \mathrm{~b}}$ However, after $4 \mathrm{~h}$ heating no expected product was found in the reaction mixture. Thus, the reaction was repeated at room temperature using glacial acetic acid as a solvent, and in this case, the desired imidazole 3 -oxide $\mathbf{1 b}$ was isolated in $47 \%$ yield. Other, $N$-bulky substituted products 1c-e were prepared in analogous manner and isolated as crystalline, stable solids in $54-75 \%$ yields. The ${ }^{1} \mathrm{H}-\mathrm{NMR}(600 \mathrm{MHz})$ spectra of all new imidazole 3-oxides $\mathbf{1 b}$-e revealed the presence of the low-field shifted singlets located between 8.18 and $7.78 \mathrm{ppm}$, characteristic for the $\mathrm{C}(2) H$ atoms. In the case of adamantan-1-yl derivatives $\mathbf{1 b}$ and $\mathbf{1 c}, \mathrm{H}$-atoms attached to adamantane skeleton formed three groups of signals identified in both cases as a broad singlet $(3 \mathrm{H})$, doublet $(6 \mathrm{H})$ and an $A B$-like system $(6 \mathrm{H})$, respectively.

Additionally, five known imidazole 3-oxides 1f-j, selected for further studies with HFAH, were prepared by heating of ethanolic solutions of corresponding 1,3,5-trialkylhexahydro-1,3,5triazines with diacetyl monooxime (product 1f), benzil monooxime (product 1h) or 1(hydroxyimino)-1-phenylpropan-2-one (products 1g,i,j, ), respectively (Figure 2).

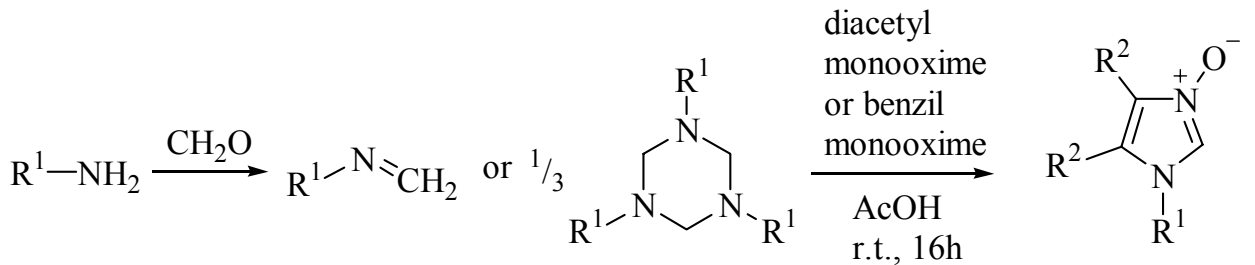

$$
\begin{aligned}
& \mathrm{R}^{1}=\mathrm{Ad}, t-\mathrm{Bu} \quad \mathrm{R}^{1}=i-\mathrm{Pr}
\end{aligned}
$$

Scheme 2. Synthesis of $N$-bulky substituted imidazole 3-oxides 1b-e.

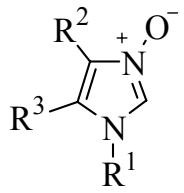

1f $\mathrm{R}^{1}=\mathrm{cHex}, \mathrm{R}^{2}=\mathrm{Me}, \mathrm{R}^{3}=\mathrm{Me}$

1g $\mathrm{R}^{1}=\mathrm{cHex}, \mathrm{R}^{2}=\mathrm{Ph}, \mathrm{R}^{3}=\mathrm{Me}$

1h $\mathrm{R}^{1}=$ cHex, $\mathrm{R}^{2}=\mathrm{Ph}, \mathrm{R}^{3}=\mathrm{Ph}$

1i $\mathrm{R}^{1}=\mathrm{Me}, \mathrm{R}^{2}=\mathrm{Ph}, \mathrm{R}^{3}=\mathrm{Me}$

1j $\mathrm{R}^{1}=$ Allyl, $\mathrm{R}^{2}=\mathrm{Ph}, \mathrm{R}^{3}=\mathrm{Me}$

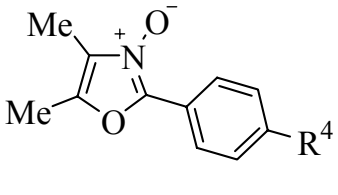

5a $\mathrm{R}^{4}=\mathrm{H}$

5b $\mathrm{R}^{4}=\mathrm{NMe}_{2}$

Figure 2. 2-Unsubstituted imidazole 3-oxides $\mathbf{1 f - j}$ and oxazole 3-oxides 5a-b. 
The reaction of $\mathbf{1 b}$ with hexafluoroacetone sesquihydrate $\left(1.5 \mathrm{H}_{2} \mathrm{O}\right)$ was carried out at room temperature in dichloromethane solution, and after $30 \mathrm{~min}$. the expected complex $\mathbf{4 b}$ was isolated in 95\% yield (Scheme 3). The same result was achieved using hexafluoroacetone trihydrate, and again 4b was obtained nearly quantitatively after standard workup (drying, solvent removal). In analogous manner, 2-unsubstituted imidazole 3-oxides 1d-j were converted into crystalline, solid complexes $\mathbf{4 d - j}$ in excellent yields (Table 1). In selected examples 1g,h,j, pure products spontaneously crystallized from reaction solutions.

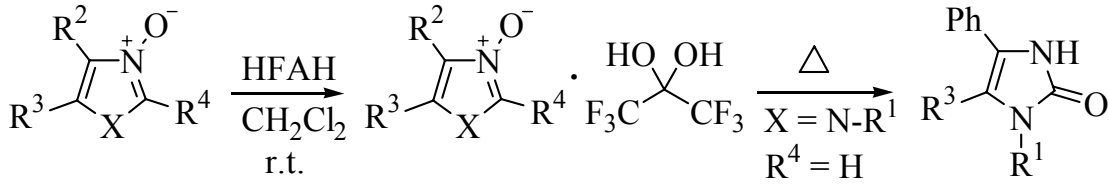

$$
\begin{aligned}
& 1 \mathrm{X}=\mathrm{N}-\mathrm{R}^{1} \quad 4 \mathrm{X}=\mathrm{N}-\mathrm{R}^{1} \quad 3 \mathrm{~h} \mathrm{R}^{1}=c \mathrm{Hex} ; \mathrm{R}^{3}=\mathrm{Ph} \\
& 5 \mathrm{X}=\mathrm{O} \quad 6 \mathrm{X}=\mathrm{O} \quad 3 \mathrm{i} \mathrm{R}^{1}=\mathrm{R}^{3}=\mathrm{Me} \\
& \text { 3j } \mathrm{R}^{1}=\text { Allyl; } \mathrm{R}^{3}=\mathrm{Me}
\end{aligned}
$$

Scheme 3. Complexation reactions of imidazole 3-oxides and oxazole 3-oxides with hexafluoroacetone hydrate (HFAH). Conversions of complexes $\mathbf{4 h}-\mathbf{j}$ into corresponding imidazol-2-ones 3h-j.

Table 1. Complexes of imidazole 3-oxides and oxazole 3-oxides with HFAH

\begin{tabular}{ccccccc}
\hline & $\mathrm{R}^{2}$ & $\mathrm{R}^{3}$ & $\mathrm{R}^{4}$ & $\mathrm{X}$ & Yield [\%] & $\begin{array}{c}\text { M.p. }\left({ }^{\circ} \mathrm{C},\right. \\
\text { decomp. })\end{array}$ \\
\hline $\mathbf{4 b}$ & $\mathrm{Me}$ & $\mathrm{Me}$ & $\mathrm{H}$ & $\mathrm{N}-(1-\mathrm{Ad})$ & 95 & $147-149$ \\
$\mathbf{4 d}$ & $\mathrm{Me}$ & $\mathrm{Me}$ & $\mathrm{H}$ & $\mathrm{N}-t \mathrm{Bu}$ & 89 & $114-116$ \\
$\mathbf{4 e}$ & $\mathrm{Me}$ & $\mathrm{Me}$ & $\mathrm{H}$ & $\mathrm{N}-\mathrm{Pr}$ & 96 & $97-98$ \\
$\mathbf{4 f}$ & $\mathrm{Me}$ & $\mathrm{Me}$ & $\mathrm{H}$ & $\mathrm{N}-c \mathrm{Hex}$ & 96 & $120-121$ \\
$\mathbf{4 g}$ & $\mathrm{Ph}$ & $\mathrm{Me}$ & $\mathrm{H}$ & $\mathrm{N}-c \mathrm{Hex}$ & 94 & $110-111$ \\
$\mathbf{4 h}$ & $\mathrm{Ph}$ & $\mathrm{Ph}$ & $\mathrm{H}$ & $\mathrm{N}-c \mathrm{Hex}$ & 92 & $114-116$ \\
$\mathbf{4 i}$ & $\mathrm{Ph}$ & $\mathrm{Me}$ & $\mathrm{H}$ & $\mathrm{N}-\mathrm{Me}$ & 88 & $90-91$ \\
$\mathbf{4 j}$ & $\mathrm{Ph}$ & $\mathrm{Me}$ & $\mathrm{H}$ & $\mathrm{N}-\mathrm{Allyl}$ & 91 & $93-94$ \\
$\mathbf{6 a}$ & $\mathrm{Me}$ & $\mathrm{Me}$ & $\mathrm{Ph}$ & $\mathrm{O}$ & 92 & $85-86$ \\
$\mathbf{6 b}$ & $\mathrm{Me}$ & $\mathrm{Me}$ & $p-\mathrm{Me}_{2} \mathrm{~N}-\mathrm{Ph}$ & $\mathrm{O}$ & 66 & $100-101$ \\
\hline
\end{tabular}


In the ${ }^{1} \mathrm{H}-\mathrm{NMR}(600 \mathrm{MHz})$ spectrum of complex $\mathbf{4 b}$, registered in $\mathrm{CDCl}_{3}$, the characteristic singlet of $\mathrm{C}(2) H$ was down-field shifted $(8.02 \mathrm{ppm})$ in comparison to the starting $\mathbf{1 b}$ (7.86 ppm) and analogous tendency was observed for all complexes 4 . The ${ }^{13} \mathrm{C}-\mathrm{NMR}$ spectra of $\mathbf{4 b}$ revealed the presence of quartet $\left({ }^{1} J_{\mathrm{C}-\mathrm{F}}=288.0 \mathrm{~Hz}\right)$ and heptet $\left({ }^{2} J_{\mathrm{C}-\mathrm{F}}=32.0 \mathrm{~Hz}\right)$ located at 121.7 and 91.1 ppm, respectively. These two characteristic signals found also in the spectra of complexes $4 \mathbf{d}-\mathbf{j}$ prove the presence of $\left(\mathrm{CF}_{3}\right)_{2} \mathrm{C}(\mathrm{OH})_{2}$ molecule in the isolated products. Because of the unique character of the hydrogen bond in complexes $4,{ }^{1 \mathrm{~d}}$ the IR spectroscopy data deserve a short comment. In the case of $\mathbf{4 b}$, the IR spectrum registered in solid $\mathrm{KBr}$ showed a set of strong and broad absorption bands located between 3432 and $2507 \mathrm{~cm}^{-1}$ which are attributed to the associated - $\mathrm{OH}$ groups. Additionally, strong bands at 1214 and $1206 \mathrm{~cm}^{-1}$ resulting from stretch vibrations of the $\mathrm{C}-\mathrm{F}$ bonds were observed in all cases.

In order to test if other azole $N$-oxides are also able to form corresponding complexes, two 2,4,5-trisubstituted oxazole 3-oxides 5a,b (Figure 2) were prepared following the literature protocol. ${ }^{8}$ Both compounds were tested in reactions with HFAH under standard conditions and the desired salts $\mathbf{6 a}, \mathbf{b}$ were isolated as crystalline materials in 92 and $66 \%$ yield, respectively (Scheme 3). Surprisingly, neither 2,3-diphenylquinoxaline bis- $N, N^{\prime}$-oxide 7 nor 3ethoxycarbonyl-1-phenyl-1,2,4-triazole $N$-oxide 8 (Figure 3) gave the expected complexation products. On one hand, a likely explanation of this fact is the more basic character of the $\mathrm{O}$ atom present in the $\mathrm{N} \rightarrow \mathrm{O}$ unit of the azoles than in the 6-membered azaaromatic $N$-oxides.

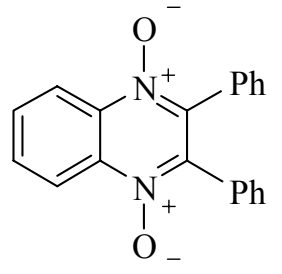

7

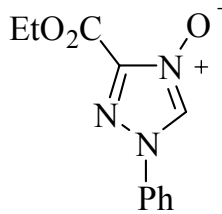

8

Figure 3. 2,3-Diphenylquinoxaline bis- $N, N$ '-oxide 7 and 3-ethoxycarbonyl-1-phenyl-1,2,4triazole $N$-oxide $\mathbf{8}$.

This effect results from advantageous stabilization of the positive charge within 5-membered azole rings. On the other hand, the presence of electron withdrawing ester moiety induces certain decrease of the electron density in heterocyclic ring what is reflected by a reduced basicity of the $\mathrm{O}$-atom in the tested 1,2,4-triazolecarboxylate.

In the series of HFAH complexes $\mathbf{4 b , d - f}$, derived from 4,5-dimethylimidazole 3-oxides, determined melting points can be considered as a qualitative measure of their stability. It depends clearly on the bulkiness of the substituent attached to the $\mathrm{N}(1)$-atom and decreases in the following order: $\mathrm{Ad}>c \mathrm{Hex} \approx t$-Bu $>i$-Pr (decomposition points: 147-149, 120-121, 114-116 and 97-98 ${ }^{\circ} \mathrm{C}$, resp., Table 1). However, replacement of Me group to $\mathrm{Ph}$ substituent at $\mathrm{C}(5)$ or/and $\mathrm{C}(4)$ atoms (complexes $\mathbf{4 g}-\mathbf{j}$ ) does not lead to significant change of decomposition point. 
Unexpectedly, isolated complexes 4 possesing $\mathrm{Ph}$ ring attached to the $\mathrm{C}(4)$-atom, decompose at melting points under extrusion of a gaseous product and yield imidazol-2-ones $\mathbf{3}$ as main products. Similarly, they undergo the same transformation while heating in boiling $\mathrm{CHCl}_{3}$ solution (or suspension). For instance, heating of $\mathbf{4 h}$ gave after $0.5 \mathrm{~h}$ desired 1-cyclohexyl-1,3dihydro-4,5-diphenyl-2H-imidazol-2-one $\mathbf{3 h}$ in 53\% yield. According to the general method, heating of complexes $\mathbf{4 h}-\mathbf{j}$ in neat furnished corresponding $\mathbf{3 h}-\mathbf{j}$ in acceptable yields (49-72\%). In the case of $\mathbf{4 d}$ and $\mathbf{4 e}$, bearing Me groups at the $\mathrm{C}(4)$-atom, decomposition yielded complex mixtures and the expected imidazol-2-ones could not be detected in the registered IR spectra of crude materials.* The observed facts suggest, that in analogy to Beckmann type rearrangement of nitrones, ${ }^{10}$ hexafluoroacetone hydrate is a prone acidic inductor (with $\mathrm{pK}_{1}=6.58\left[\mathrm{H}_{2} \mathrm{O}, 25\right.$ $\left.\left.{ }^{\circ} \mathrm{C}\right]\right)^{11}$ for the isomerisation of the $\mathrm{Ph}-\mathrm{C}(4)$-substituted imidazole 3-oxides 1 into corresponding imidazol-2-ones 3; the proposed reaction pathway is presented in Scheme 4.

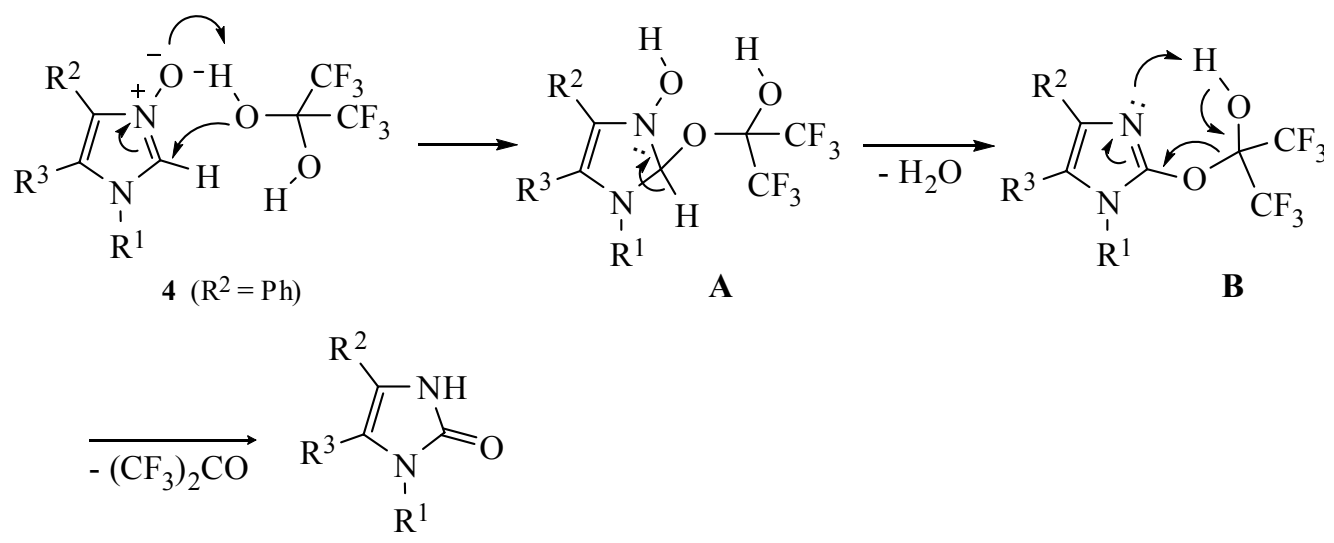

Scheme 4. Mechanism of Brönstedt acid catalysed isomerisation of complexes 4 into imidazol2-ones 3.

In the initial step HFAH is proposed to undergo addition onto imidazole 3-oxide yielding the intermediate adduct $\mathbf{A}$. Next, rearomatization of imidazole ring leads to elimination of water molecule and hemiacetal $\mathbf{B}$ is probably formed. The latter undergoes further conversion via 1,5$\mathrm{H}$ shift into imidazol-2-one $\mathbf{3}$ and hexafluoroacetone as a side product. It is noteworthy, that in the CI-MS spectrum of $4 \mathbf{i}$, one of the four main mass peaks is $355\left(8 \%,\left[M-\mathrm{H}_{2} \mathrm{O}+1\right]^{+}\right)$which can be attributed to the hemiacetal structure of type B. Analogous fragmentation was observed in the case of $\mathbf{4 g}$. These observations support the mechanism presented in Scheme 4.

Conversions of 2-unsubstituted imidazole 3-oxides with cycloaliphatic thioketones are considered as a straightforward method for preparation of imidazole-2-thiones via so called 'sulfur transfer reaction'. 'a,f, 12 Now, the question arises if complexes $\mathbf{4}$ are also able to undergo the same transformation under typical conditions (room temperature, dichloromethane or chloroform as a solvent). In order to answer this question, a test experiment with the complex $\mathbf{4 f}$ 
and 2,2,4,4-tetramethylcyclobutane-1,3-dithione ${ }^{1 \mathrm{a}}$ was carried out in chloroform solution. In contrast to the parent 3-oxide 1f, which was completely converted into 1-cyclohexyl-4,5dimethylimidazole-2-thione within 30 min., ${ }^{1 a}$ complex 4 f reacts sluggishly and the conversion was completed only after 3 days (TLC monitoring). Apparently, complexes 4 dissociate in the solution and exist in an equilibrium with little amount of 'free' $N$-oxide and hexafluoroacetone hydrate.

\section{Conclusions}

The study showed, that the $N$-bulky substituted imidazole 3-oxides 1b-d, bearing at the $\mathrm{N}(1)$ atom extremely large groups, like 1-adamantanyl or tert-butyl, can be prepared in satisfactory yields using a simple and efficient protocol for condensation of $\alpha$-(hydroxyimino)ketones with corresponding monomeric formaldimines in glacial acetic acid at room temperature. The alternative method based on the heating of the same substrates in ethanolic solution turned out completely useless for preparation of these type of products. The obtained imidazole 3-oxides 1b-d are potentially attractive starting materials for the synthesis of new, stable nucleophilic carbenes (NHC) via three step deoxygenation-quaternization-elimination procedure.

Imidazole 3-oxides 1, irrespectively of the substitution pattern, easily react with hexafluoroacetone hydrate yielding stable, crystalline 1:1 complexes 4 in nearly quantitative yields. Similar complexes displaying the same stoichiometry were obtained with oxazole 3oxides 5. To the best of our knowledge this is the first example of successful exploration of commercially available hexafluoroacetone hydrate for complexation of azaaromatic $N$-oxides.

The 4-phenyl-substituted complexes $\mathbf{4 h}-\mathbf{j}$ decompose at melting point temperature, as well as upon heating in $\mathrm{CHCl}_{3}$ solutions, to afford the corresponding imidazol-2-ones $\mathbf{3 h} \mathbf{\mathbf { j }}$, isomeric with the starting imidazole 3-oxides $\mathbf{1}$.

In analogy to parent 3-oxides $\mathbf{1}$, their complexes $\mathbf{4}$ can be transformed into corresponding imidazole-2-thiones via 'sulfur transfer reaction' with 2,2,4,4-tetramethylcyclobutane-1,3dithione. However, reaction is significantly slower and according to the test experiment with $\mathbf{4 f}$ requires ca. 3 days at room temperature.

\section{Experimental Section}

General. Melting points were determined in a capillary using a Mel-Temp. II apparatus (Aldrich) and are uncorrected. The IR spectra were recorded on a NEXUS FT-IR spectrophotometer in $\mathrm{KBr}$; absorptions $(y)$ in $\mathrm{cm}^{-1}$. The ${ }^{1} \mathrm{H}-,{ }^{13} \mathrm{C}-$, and ${ }^{19} \mathrm{~F}-\mathrm{NMR}$ spectra were measured on a Bruker Avance III (600 and $150 \mathrm{MHz}$, resp.) or Bruker AC 300 (300 and 75.5 $\mathrm{MHz}$, resp.) instruments using $\mathrm{CDCl}_{3}$ or $\mathrm{CD}_{3} \mathrm{OD}$ as solvents. Chemical shifts $(\delta)$ are given in ppm (TMS $=0 \mathrm{ppm})$ and coupling constants $J$ in Hz. The multiplicity of the ${ }^{13} \mathrm{C}$ signals was 
deduced from DEPT or multidimentional spectra. The MS spectra were measured on Varian 500MS or Finnigan MAT-95 instruments. Elemental analyses were performed in the laboratory of Polish Academy of Sciences in Łódź.

Starting materials. Applied reagents such as alkylamines, ketones, aldehydes, hexafluoroacetone trihydrate and solvents are commercially available (Aldrich) and were used as received. 1,3,5-Triisopropyl hexahydro-1,3,5-triazine and formaldimines derived from tertbutylamine and 1-aminoadamantane were prepared according to published protocols. ${ }^{9}$ Imidazole 3-oxides 1f-j were prepared following the already described, general method. ${ }^{1 \mathrm{c}, \mathrm{d}}$ 2-Substituted 4,5-dimethyloxazole 3-oxides 5 were prepared from diacetyl monoxime and appropriate aldehyde (benzaldehyde and $p$-[N,N-dimethylamine]benzaldehyde, resp.) in glacial acetic acid according to literature protocol. ${ }^{8}$

\section{Synthesis of imidazole 3-oxides (1b-e)}

A soln. of diacetyl monooxime $(10 \mathrm{mmol}, 1.0 \mathrm{~g})$ or benzil monooxime $(10 \mathrm{mmol}, 2.3 \mathrm{~g})$ and appropriate formaldimine $\left(10 \mathrm{mmol}, \mathrm{R}^{1}=\mathrm{Ad}, t-\mathrm{Bu}\right)$ or hexahydro-1,3,5-triazine $\left(3.3 \mathrm{mmol}, \mathrm{R}^{1}=\right.$ $i$ - $\mathrm{Pr}, 0.70 \mathrm{~g})$ in glacial $\mathrm{AcOH}(10 \mathrm{ml})$ was stirred overnight at r.t. Then, gaseous $\mathrm{HCl}$ was bubbled through the soln. for $1 \mathrm{~h}$ at $0{ }^{\circ} \mathrm{C}$, and $\mathrm{Et}_{2} \mathrm{O}$ (typically $c a .200 \mathrm{ml}$ ) was added. The crude hydrochloride was separated, washed with $\mathrm{Et}_{2} \mathrm{O}(3 \times 30 \mathrm{ml})$ and dissolved in $\mathrm{CHCl}_{3} / \mathrm{MeOH}$ mixture $(5: 1,30 \mathrm{ml})$. The resulting soln. was treated with excess solid $\mathrm{Na}_{2} \mathrm{CO}_{3}$, stirred for $c a .30$ min, filtered, and the solvent was removed in vacuo. Crude products 1 were purified by column chromatography on silica using first acetone and then MeOH/AcOEt mixture (1:1). Crystallization from appropriate solvent led to analytically pure products. In the case of $\mathbf{1 c}$ crystalline product precipitated from the solution after neutralization of hydrochloride with sodium carbonate.

1-Adamantyl-4,5-dimethyl-1 $\boldsymbol{H}$-imidazole 3-oxide (1b). Colorless solid, yield $47 \%, 1.16 \mathrm{~g}, \mathrm{R}_{f}=$ 0.41, mp 180-182 ${ }^{\circ} \mathrm{C}$ (decomp.) $\left(\mathrm{CH}_{2} \mathrm{Cl}_{2} / \mathrm{Et}_{2} \mathrm{O}\right)$, IR: 2909vs, $2849 \mathrm{~s}, 1456 \mathrm{~m}, 1373 \mathrm{~m}, 1339 \mathrm{~m}$, $1320 \mathrm{~m}, 1308 \mathrm{~s}, 1225 \mathrm{~s}, 1180 \mathrm{~m}, 1151 \mathrm{~m} .{ }^{1} \mathrm{H}$ NMR $\left(600 \mathrm{MHz}, \mathrm{CDCl}_{3}\right), 7.86(\mathrm{~s}, 1 \mathrm{H}, \mathrm{C}(2)-\mathrm{H}), 2.35$ (s, 3H, Me), 2.32 (br. s, 3H, Ad), 2.16 (s, 3H, Me), 2.12 (d, $J=2.4,6 \mathrm{H}, \mathrm{Ad}), 1.76,1.71$ (2d, $J=$ 12.6, 6H, Ad). ${ }^{13} \mathrm{C}$ NMR (150 MHz, $\left.\mathrm{CDCl}_{3}\right), 128.0$ and 120.5 (2s, C(4), C(5)), 122.5 (d, C(2)), 58.9 (s, C(Ad)), 42.1 (t, $\mathrm{CH}_{2}(\mathrm{Ad})$ ), 35.6 (d, $\mathrm{CH}(\mathrm{Ad})$ ), 29.5 (t, $\mathrm{CH}_{2}(\mathrm{Ad})$ ), 12.7, 7.0 (2q, 2Me). ESI-MS, $269\left(12,[M+\mathrm{Na}]^{+}\right), 246\left(100, M^{+}\right)$. ESI-HRMS, found 247.1807 (for $[M+1]^{+}$, $\mathrm{C}_{15} \mathrm{H}_{23} \mathrm{~N}_{2} \mathrm{O}$ ), Calcd 247.1805.

1-Adamantyl-4,5-diphenyl-1 $\boldsymbol{H}$-imidazole 3-oxide (1c). Colorless solid, yield 54\%, $2.00 \mathrm{~g}, \mathrm{mp}$ $238-241{ }^{\circ} \mathrm{C}$ (decomp.) $\left(\mathrm{CH}_{2} \mathrm{Cl}_{2} / \mathrm{Et}_{2} \mathrm{O}\right)$, IR: 3055s, 2911vs, 2853s, $1443 \mathrm{~m}, 1342 \mathrm{~m}, 1306 \mathrm{~s}, 1243 \mathrm{~s}$, 1170m, 1151m, 751s, 696s. ${ }^{1} \mathrm{H}$ NMR (600 MHz, $\left.\mathrm{CDCl}_{3}\right), 8.18$ (s, 1H, C(2)-H), 7.46-7.33 (m, 7 arom. $\mathrm{CH}$ ); 7.22-7.16 (m, 3 arom. $\mathrm{CH}$ ); 2.11 (br. s, 3H, Ad); 2.06 (d, J=2.4, 6H, Ad); 1.65, 1.53 $(2 \mathrm{~d}, J=12.0,6 \mathrm{H}, \mathrm{Ad}) .{ }^{13} \mathrm{C} \mathrm{NMR}\left(150 \mathrm{MHz}, \mathrm{CDCl}_{3}\right)$ : 132.0, 130.5, 127.0, 126.6 (4s, 4 arom. C), 132.7, 129.7, 129.5, 128.3, 127.8, 127, 7, 123.8 (7d for 11 arom $\mathrm{CH}) ; 58.9$ (s, C(Ad)); 43.1 (t, 
$\left.\mathrm{CH}_{2}(\mathrm{Ad})\right) ; 35.4$ (d, $\left.\mathrm{CH}(\mathrm{Ad})\right) ; 29.5$ (t, $\left.\mathrm{CH}_{2}(\mathrm{Ad})\right)$. EI-MS: $370\left(15, M^{+}\right), 354$ (40, [M-O] $\left.{ }^{+}\right), 135$ $\left(100,\left[\mathrm{C}_{10} \mathrm{H}_{15}\right]^{+}\right.$). EI-HRMS, found 370.2045 (for $\left[M^{+}\right], \mathrm{C}_{25} \mathrm{H}_{26} \mathrm{~N}_{2} \mathrm{O}$ ), Calcd 370.2049.

1-tert-Butyl-4,5-dimethyl-1H-imidazole 3-oxide (1d). Light yellow semi-solid, yield 58\%, 0.97 $\mathrm{g}, \mathrm{R}_{f}=0.31$, IR: $2987 \mathrm{~m}, 2942 \mathrm{~m}, 1647 \mathrm{~m}, 1621 \mathrm{~m}, 1468 \mathrm{~m}, 1457 \mathrm{~m}, 1376 \mathrm{~s}, 1362 \mathrm{~m}, 1318 \mathrm{~s}, 1207 \mathrm{~s}$, 1174m, 1132m. ${ }^{1} \mathrm{H}$ NMR (600 MHz, $\mathrm{CDCl}_{3}$ ), 7.95 (s, 1H, C(2)-H), 2.31, 2.16 (2s, 6H, 2Me), $1.58(\mathrm{~s}, 9 \mathrm{H}, t-\mathrm{Bu}) .{ }^{13} \mathrm{C} \mathrm{NMR}\left(150 \mathrm{MHz}, \mathrm{CDCl}_{3}\right), 127.9$ and 120.8 (2s, C(4), C(5)), 123.1 (d, $\mathrm{C}(2)), 57.5(\mathrm{~s}, \mathrm{C}(t-\mathrm{Bu})), 29.8\left(\mathrm{q}, 3 \mathrm{CH}_{3}(t-\mathrm{Bu})\right), 11.9$ and $6.9(2 \mathrm{q}, 2 \mathrm{Me})$. ESI-MS, 191 (75, $\left.[M+\mathrm{Na}]^{+}\right), 168\left(100, M^{+}\right)$. ESI-HRMS, found 169.1335 (for $[M+1]^{+}, \mathrm{C}_{9} \mathrm{H}_{17} \mathrm{~N}_{2} \mathrm{O}$ ), Calcd 169.1335 .

4,5-Dimethyl-1-isopropyl-1H-imidazole 3-oxide (1e). Colorless crystals, yield 65\%, $1.0 \mathrm{~g}, \mathrm{R}_{f}=$ 0.37, mp 52-57 ${ }^{\circ} \mathrm{C}\left(\mathrm{CH}_{2} \mathrm{Cl}_{2} / \mathrm{Et}_{2} \mathrm{O}\right)$, IR: 3230s, 3125s, 2973s, 1623m, 1410m, 1378m, 1335vs, $1215 \mathrm{~m}, 1198 \mathrm{~m}, 1142 \mathrm{~m}, 823 \mathrm{~m} .{ }^{1} \mathrm{H}$ NMR $\left(600 \mathrm{MHz}, \mathrm{CDCl}_{3}\right), 7.78$ (s, 1H, C(2)-H), 4.22-4.18 (m, $1 \mathrm{H}, i$-Pr), 2.14 and $2.13(2 \mathrm{~s}, 6 \mathrm{H}, 2 \mathrm{Me}), 1.39\left(\mathrm{~d}, J=6.6,6 \mathrm{H}, i\right.$-Pr). ${ }^{13} \mathrm{C} \mathrm{NMR}\left(150 \mathrm{MHz}, \mathrm{CDCl}_{3}\right)$,

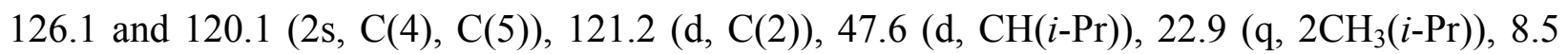
and $6.9(2 \mathrm{q}, 2 \mathrm{Me})$. ESI-MS, $176\left(26,[M+\mathrm{Na}-1]^{+}\right), 154\left(100, M^{+}\right), 136$ (44), 112 (43). ESIHRMS, found 155.1181 (for $[M+1]^{+}, \mathrm{C}_{8} \mathrm{H}_{15} \mathrm{~N}_{2} \mathrm{O}$ ), Calcd 155.1179 .

\section{General procedure for preparation of complexes (4 and 6)}

To the solution of azole $N$-oxide $(1.0 \mathrm{mmol})$ in $2 \mathrm{ml}$ of $\mathrm{CH}_{2} \mathrm{Cl}_{2}$, hexafluoroacetone trihydrate (HFAH, $1.0 \mathrm{mmol}, 0.22 \mathrm{~g}$ ) was added at $0{ }^{\circ} \mathrm{C}$. Resulting mixture was magnetically stirred for 30 min and next diluted with $\mathrm{CH}_{2} \mathrm{Cl}_{2}$ (ca. $10 \mathrm{ml}$ ) (in the case of $\mathbf{4 g}, \mathbf{4 h}$ and $\mathbf{4 i}$ amount of 20-30 $\mathrm{ml}$ was necessary in order to dissolve the precipitated product). Organics were separated, dried with anhydrous $\mathrm{MgSO}_{4}$, filtered, and the solvent was removed in vacuo from cold water bath to give crude product (4 or 6) as a colorless solid. Analytically pure samples were obtained by recrystallization from appropriate solvents.

Complex of 1-adamantyl-4,5-dimethyl-1H-imidazole 3-oxide with HFAH (4b). Colorless crystals, yield 95\%, $408 \mathrm{mg}$, mp 147-149 ${ }^{\circ} \mathrm{C}$ (decomp.) (Et $\left.{ }_{2} \mathrm{O}\right)$, IR: 3432vs (br.), 3194m, 2926vs, 2862m, 2636s (br.), 2507s (br.), 1364m, 1308s, 1214vs, 1206vs, 1151s, 1095s, 957m. ${ }^{1} \mathrm{H}$ NMR $\left(600 \mathrm{MHz}, \mathrm{CDCl}_{3}\right), 8.02$ (s, 1H, C(2)-H), 2.37 (s, 3H, Me), 2.26 (br. s, 3H, Ad), 2.15 (d, J = 3.0, $6 \mathrm{H}, \mathrm{Ad}), 2.14$ (s, 3H, Me), 1.78 and $1.74(2 \mathrm{~d}, J=12.6,6 \mathrm{H}, \mathrm{Ad}) .{ }^{13} \mathrm{C} \mathrm{NMR}\left(150 \mathrm{MHz}, \mathrm{CDCl}_{3}\right)$, 127.8 and $120.9(2 \mathrm{~s}, \mathrm{C}(4), \mathrm{C}(5)), 124.4(\mathrm{~d}, \mathrm{C}(2)), 121.7\left(\mathrm{q},{ }^{1} J_{\mathrm{C}-\mathrm{F}}=288.0,2 \mathrm{CF}_{3}\right), 91.1$ (hept, ${ }^{2} J_{\mathrm{C}-\mathrm{F}}$ $\left.=32.0, C\left(\mathrm{CF}_{3}\right)_{2}\right), 59.7$ (s, N-C(Ad)), $41.8\left(\mathrm{t}, \mathrm{CH}_{2}(\mathrm{Ad})\right), 35.6(\mathrm{~d}, \mathrm{CH}(\mathrm{Ad})), 29.6\left(\mathrm{t}, \mathrm{CH}_{2}(\mathrm{Ad})\right)$, 12.5 and $6.7(2 \mathrm{q}, 2 \mathrm{Me}) .{ }^{19} \mathrm{~F}$ NMR $\left(\mathrm{CDCl}_{3}\right),-83.1 \quad\left(\mathrm{~s}, 2 \mathrm{CF}_{3}\right)$. CI-MS, 247 (100, [M$\left.\mathrm{C}_{3} \mathrm{H}_{2} \mathrm{~F}_{6} \mathrm{O}_{2}+1\right]^{+}$).

Complex of 1-tert-butyl-4,5-dimethyl-1H-imidazole 3-oxide with HFAH (4d). Colorless crystals, yield 89\%, $314 \mathrm{mg}$, mp $114-116^{\circ} \mathrm{C}$ (decomp.) (Et $\left.2 \mathrm{O}\right)$, IR: 3442vs (br.); 3194m, 2987m, 2630vs (br.), 2502vs (br.), 1319m, 1216vs, 1198vs, 1150m, 1092s, 960m. ${ }^{1} \mathrm{H}$ NMR (600 MHz, $\left.\mathrm{CDCl}_{3}\right), 8.06(\mathrm{~s}, 1 \mathrm{H}, \mathrm{C}(2)-\mathrm{H}), 2.33$ and $2.15(2 \mathrm{~s}, 6 \mathrm{H}, 2 \mathrm{Me}), 1.61(\mathrm{~s}, 9 \mathrm{H}, t-\mathrm{Bu}) .{ }^{13} \mathrm{C}$ NMR $(150$ $\mathrm{MHz}_{\mathrm{CDCl}}$ ), 128.0 and $121.0(2 \mathrm{~s}, \mathrm{C}(4), \mathrm{C}(5)), 124.7(\mathrm{~d}, \mathrm{C}(2)), 121.7$ (q, $\left.{ }^{1} J_{\mathrm{C}-\mathrm{F}}=288.0,2 \mathrm{CF}_{3}\right)$, 
91.1 (hept, $\left.{ }^{2} J_{\mathrm{C}-\mathrm{F}}=32.2, C\left(\mathrm{CF}_{3}\right)_{2}\right), 58.6(\mathrm{~s}, \mathrm{C}(t-\mathrm{Bu})), 29.7\left(\mathrm{q}, 3 \mathrm{CH}_{3}(t-\mathrm{Bu})\right), 11.9$ and $6.8(2 \mathrm{q}$, 2Me). ${ }^{19} \mathrm{~F} \mathrm{NMR}\left(\mathrm{CDCl}_{3}\right),-83.1$ (s, 2CF $)$. CI-MS, $169\left(100,\left[M-\mathrm{C}_{3} \mathrm{H}_{2} \mathrm{~F}_{6} \mathrm{O}_{2}+1\right]^{+}\right)$.

Complex of 4,5-dimethyl-1-isopropyl-1H-imidazole 3-oxide with HFAH (4e). Colorless crystals ,yield 96\%, $324 \mathrm{mg}$, mp 97-98 ${ }^{\circ} \mathrm{C}$ (decomp.) (Et $\left.2 \mathrm{O}\right)$, IR: 3427vs (br.), 3177m, 2994m, 2939m, 2634vs (br.), 2491vs (br.), 1345s, 1217vs, 1197vs, 1093s, 965m. ${ }^{1} \mathrm{H}$ NMR (600 MHz, $\left.\mathrm{CDCl}_{3}\right), 8.02(\mathrm{~s}, 1 \mathrm{H}, \mathrm{C}(2)-\mathrm{H}), 4.28-4.24(\mathrm{~m}, 1 \mathrm{H}, i-\mathrm{Pr}), 2.18$ and $2.16(2 \mathrm{~s}, 6 \mathrm{H}, 2 \mathrm{Me}), 1.45(\mathrm{~d}, J=$ 6.6, 6H, i-Pr). ${ }^{13} \mathrm{C}$ NMR (150 MHz, $\left.\mathrm{CDCl}_{3}\right), 126.3$ and $120.4(2 \mathrm{~s}, \mathrm{C}(4), \mathrm{C}(5)), 123.5(\mathrm{~d}, \mathrm{C}(2))$, $121.7\left(\mathrm{q},{ }^{1} J_{\mathrm{C}-\mathrm{F}}=288.0,2 \mathrm{CF}_{3}\right), 91.1\left(\mathrm{hept},{ }^{2} J_{\mathrm{C}-\mathrm{F}}=31.9, C\left(\mathrm{CF}_{3}\right)_{2}\right), 48.4(\mathrm{~d}, \mathrm{CH}(i-\mathrm{Pr})), 22.8(\mathrm{q}$, $2 \mathrm{CH}_{3}(i$-Pr $\left.)\right), 8.5$ and $6.7(2 \mathrm{q}, 2 \mathrm{Me}) .{ }^{19} \mathrm{~F} \mathrm{NMR}\left(\mathrm{CDCl}_{3}\right),-83.1\left(\mathrm{~s}, 2 \mathrm{CF}_{3}\right) . \mathrm{CI}-\mathrm{MS}, 155$ (100, [M$\left.\mathrm{C}_{3} \mathrm{H}_{2} \mathrm{~F}_{6} \mathrm{O}_{2}+1\right]^{+}$).

Complex of 1-cyclohexyl-4,5-dimethyl-1H-imidazole 3-oxide with HFAH (4f). Colorless crystals, yield 96\%, $363 \mathrm{mg}$, mp 120-121 ${ }^{\circ} \mathrm{C}$ (decomp.) (Et $\left.{ }_{2} \mathrm{O}\right)$, IR: 3442vs (br.), 3167m, 2939m, 2862m, 2619s (br.), 2484vs (br.) 1339m, 1212vs, 1200vs, 1153m, 1091s, 964m. ${ }^{1} \mathrm{H}$ NMR (600 $\left.\mathrm{MHz}, \mathrm{CDCl}_{3}\right), 8.00$ (s, 1H, C(2)-H), 3.81-3.76 (m, 1H, $\left.c \mathrm{Hex}\right), 2.16$ and $2.15(2 \mathrm{~s}, 6 \mathrm{H}, 2 \mathrm{Me}), 2.04-$ $1.92(\mathrm{~m}, 4 \mathrm{H}, c \mathrm{Hex}), 1.78-1.74(\mathrm{~m}, 1 \mathrm{H}, c \mathrm{Hex}), 1.57-1.36(\mathrm{~m}, 4 \mathrm{H}, c \mathrm{Hex}), 1.29-1.24(\mathrm{~m}, 1 \mathrm{H}$, cHex). ${ }^{13} \mathrm{C}$ NMR (150 MHz, $\left.\mathrm{CDCl}_{3}\right), 126.0$ and 120.4 (2s, C(4), C(5)), 123.8 (d, C(2)), 121.7 (q, $\left.\left.{ }^{1} J_{\mathrm{C}-\mathrm{F}}=288.0,2 \mathrm{CF}_{3}\right), 91.1\left(\mathrm{hept},{ }^{2} J_{\mathrm{C}-\mathrm{F}}=32.2, C\left(\mathrm{CF}_{3}\right)_{2}\right), 55.9(\mathrm{~d}, \mathrm{CH}, c \mathrm{Hex})\right), 33.5,25.4$ and 24.8 $\left.\left(3 \mathrm{t}, 5 \mathrm{CH}_{2}, c \mathrm{Hex}\right)\right), 8.5$ and $6.7(2 \mathrm{q}, 2 \mathrm{Me}) .{ }^{19} \mathrm{~F} \mathrm{NMR}\left(\mathrm{CDCl}_{3}\right),-83.1$ (s, 2CF $)$. CI-MS, 195 (100, $\left[M-\mathrm{C}_{3} \mathrm{H}_{2} \mathrm{~F}_{6} \mathrm{O}_{2}+1\right]^{+}$).

Complex of 1-cyclohexyl-5-methyl-4-phenyl-1H-imidazole 3-oxide with HFAH (4g). Colorless crystals, yield 94\%, $414 \mathrm{mg}, \mathrm{mp} 110-111{ }^{\circ} \mathrm{C}$ (decomp.) (Et ${ }_{2} \mathrm{O}$ ), IR: 3428vs (br.); 2939s, 2862m, 2646vs (br.), 2507vs (br.), 1364m, 1340m, 1214vs (br.), 1092s, 959m, 720m. ${ }^{1} \mathrm{H}$ NMR (600 MHz, $\left.\mathrm{CDCl}_{3}\right), 8.12(\mathrm{~s}, 1 \mathrm{H}, \mathrm{C}(2)-\mathrm{H}), 7.53-7.51$ (m, 2 arom. H), 7.47-7.44 (m, 2 arom. H), 7.41-7.39 (m, 1 arom. H), 3.90-3.87 (m, 1H, cHex), $2.28(\mathrm{~s}, 3 \mathrm{H}, \mathrm{Me}), 2.09-1.95(\mathrm{~m}, 4 \mathrm{H}$, $c \mathrm{Hex}), 1.77-1.75$ (m, 1H, cHex), 1.62-1.24 (m, 5H, $c \mathrm{Hex}) .{ }^{13} \mathrm{C}$ NMR (150 MHz, $\left.\mathrm{CDCl}_{3}\right), 130.0$, 128.8, 128.4 and 126.2 (4d, 5 arom. $\mathrm{CH}, \mathrm{C}(2)), 129.4,128.5$ and 124.8 (3s, C(Ph), C(4), C(5)), $122.5\left(\mathrm{q},{ }^{1} J_{\mathrm{C}-\mathrm{F}}=289.1,2 \mathrm{CF}_{3}\right), 91.0\left(\mathrm{hept},{ }^{2} J_{\mathrm{C}-\mathrm{F}}=27.8, C\left(\mathrm{CF}_{3}\right)_{2}\right), 56.3(\mathrm{~d}, \mathrm{CH}, c \mathrm{Hex}), 33.4,25.5$ and 24.7 (3t, $\left.5 \mathrm{CH}_{2}, c \mathrm{Hex}\right), 9.2$ (q, Me). ${ }^{19} \mathrm{~F}$ NMR $\left(\mathrm{CDCl}_{3}\right),-81.8$ (s, 2CF ). CI-MS, 423 (10, $\left.\left[M-\mathrm{H}_{2} \mathrm{O}+1\right]^{+}\right), 257\left(100,\left[M-\mathrm{C}_{3} \mathrm{H}_{2} \mathrm{~F}_{6} \mathrm{O}_{2}+1\right]^{+}\right)$.

Complex of 1-cyclohexyl-4,5-diphenyl-1H-imidazole 3-oxide with HFAH (4h). Colorless crystals, yield 92\%, $462 \mathrm{mg}, \mathrm{mp} 114-116{ }^{\circ} \mathrm{C}$ (decomp.) (Et $\left.{ }_{2} \mathrm{O}\right)$, IR: 3424vs (br.); 2939s, 2860m, 2649vs (br.), 2514vs (br.), 1447m, 1340m, 1262m, 1209vs (br.), 1174m, 1092s, 959m. ${ }^{1} \mathrm{H}$ NMR (600 MHz, $\mathrm{CDCl}_{3}$ ), 8.40 (s, 1H, C(2)-H), 7.48-7.41 (m, 5 arom. H), 7.24 (br. s, 5 arom. H), 3.81$3.76(\mathrm{~m}, 1 \mathrm{H}, c \mathrm{Hex}), 2.00-1.81(\mathrm{~m}, 4 \mathrm{H}, c \mathrm{Hex}), 1.63-1.16(\mathrm{~m}, 6 \mathrm{H}, c \mathrm{Hex}) .{ }^{13} \mathrm{C} \mathrm{NMR}(150 \mathrm{MHz}$, $\left.\mathrm{CDCl}_{3}\right), 131.3,130.8,129.8 .0,129.2,128.9,128.2$ and 125.5 (7d, 10 arom. $\left.\mathrm{CH}, \mathrm{C}(2)\right), 129.7$, 128.3, 127.8 and $126.3(4 \mathrm{~s}, 2 \mathrm{C}(\mathrm{Ph}), \mathrm{C}(4), \mathrm{C}(5)), 121.7\left(\mathrm{q},{ }^{1} J_{\mathrm{C}-\mathrm{F}}=288.5,2 \mathrm{CF}_{3}\right), 91.2\left(\right.$ hept, ${ }^{2} J_{\mathrm{C}-\mathrm{F}}$ $\left.=32.2, C\left(\mathrm{CF}_{3}\right)_{2}\right), 56.3(\mathrm{~d}, \mathrm{CH}, c \mathrm{Hex}), 34.0,25.6$ and $24.6\left(3 \mathrm{t}, 5 \mathrm{CH}_{2}, c \mathrm{Hex}\right) .{ }^{19} \mathrm{~F} \mathrm{NMR}\left(\mathrm{CDCl}_{3}\right)$, $-82.4\left(\mathrm{~s}, 2 \mathrm{CF}_{3}\right)$. CI-MS, $319\left(100,\left[M-\mathrm{C}_{3} \mathrm{H}_{2} \mathrm{~F}_{6} \mathrm{O}_{2}+1\right]^{+}\right)$.

Complex of 1,5-dimethyl-4-phenyl-1H-imidazole 3-oxide with HFAH (4i). Colorless crystals, yield 88\%, $327 \mathrm{mg}, \mathrm{mp} 90-91{ }^{\circ} \mathrm{C}$ (decomp.) $\left(\mathrm{CH}_{2} \mathrm{Cl}_{2} / \mathrm{Et}_{2} \mathrm{O}\right)$, IR: 3424vs (br.), 3173m, 3061m, 
2640vs (br.), 2510vs (br.), 1400m, 1220vs (br.), 1180m, 1094s, 960m. ${ }^{1} \mathrm{H}$ NMR (300 MHz, $\mathrm{CDCl}_{3}$ ), 8.25 (s, 1H, C(2)-H), 7.59-7.55 (m, 2 arom. H), 7.50-7.38 (m, 3 arom. H), 3.67 and 2.26 $(2 \mathrm{~s}, 6 \mathrm{H}, 2 \mathrm{Me}) .{ }^{13} \mathrm{C} \mathrm{NMR}\left(75 \mathrm{MHz}, \mathrm{CDCl}_{3}\right), 131.1,129.8,129.5$ and 128.3 (4d, 5 arom. $\mathrm{CH}$, $\mathrm{C}(2)), 130.6,128.2$ and $125.9(3 \mathrm{~s}, \mathrm{C}(\mathrm{Ph}), \mathrm{C}(4), \mathrm{C}(5)), 122.7$ (q, $\left.{ }^{1} J_{\mathrm{C}-\mathrm{F}}=289.1,2 \mathrm{CF}_{3}\right), 94.4$ (hept, $\left.{ }^{2} J_{\mathrm{C}-\mathrm{F}}=33.5, C\left(\mathrm{CF}_{3}\right)_{2}\right), 32.9$ and $9.1(2 \mathrm{q}, 2 \mathrm{Me}) .{ }^{19} \mathrm{~F} \mathrm{NMR}\left(\mathrm{CDCl}_{3}\right),-82.1\left(\mathrm{~s}, 2 \mathrm{CF}_{3}\right)$. CI-MS, 355 $\left(8,\left[M-\mathrm{H}_{2} \mathrm{O}+1\right]^{+}\right), 189\left(100,\left[M-\mathrm{C}_{3} \mathrm{H}_{2} \mathrm{~F}_{6} \mathrm{O}_{2}+1\right]^{+}\right), 173$ (53), 159 (21).

Complex of 5-methyl-4-phenyl-1-(prop-2-enyl)-1H-imidazole 3-oxide with HFAH (4j). The product was obtained from mother liquor by additon of $\mathrm{Et}_{2} \mathrm{O}(10 \mathrm{ml})$, and stored at 2-8 ${ }^{\circ} \mathrm{C}$. Colorless crystals, yield 91\%, $362 \mathrm{mg}, \mathrm{mp} 93-94{ }^{\circ} \mathrm{C}$ (decomp.) $\left(\mathrm{CH}_{2} \mathrm{Cl}_{2} / \mathrm{Et}_{2} \mathrm{O}\right)$, IR: 3432vs (br.), 3166s, 3064m, 2834vs (br.), 2679vs (br.), 2527vs (br.), 1411m, 1271m, 1028vs, $1175 \mathrm{~m}, 1150 \mathrm{~m}$, 1095s, 961m. ${ }^{1} \mathrm{H}$ NMR (600 MHz, $\mathrm{CDCl}_{3}$ ), 8.22 (s, 1H, C(2)-H), 7.52-7.50 (m, 2 arom. H), 7.46$7.41(\mathrm{~m}, 3$ arom. $\mathrm{H}), 5.92-5.87(\mathrm{~m},-\mathrm{CH}=), 5.41-5.38\left(\mathrm{~m}, 1 \mathrm{H},=\mathrm{CH}_{2}\right), 5.23-5.19\left(\mathrm{~m}, 1 \mathrm{H},=\mathrm{CH}_{2}\right)$, 4.51-4.49 (m, $\left.\mathrm{CH}_{2}\right), 2.25(\mathrm{~s}, \mathrm{Me}) .{ }^{19} \mathrm{~F}$ NMR $\left(\mathrm{CDCl}_{3}\right),-83.0\left(\mathrm{~s}, 2 \mathrm{CF}_{3}\right) . \mathrm{CI}-\mathrm{MS}, 215(100,[M-$ $\left.\mathrm{C}_{3} \mathrm{H}_{2} \mathrm{~F}_{6} \mathrm{O}_{2}+1\right]^{+}$). Anal. Calcd for $\mathrm{C}_{13} \mathrm{H}_{14} \mathrm{~N}_{2} \mathrm{O} \cdot \mathrm{C}_{3} \mathrm{H}_{2} \mathrm{~F}_{6} \mathrm{O}_{2}$ (398.31): C, 48.25; H, 4.05; N, 7.03\%, Found: C, 48.19; H, 4.19; N, 6.95\%.

Complex of 4,5-dimethyl-2-phenyloxazole 3-oxide with HFAH (6a). The highly pure product precipitates from mother liquor and was analyzed without further handling. Colorless crystals, yield 92\%, $343 \mathrm{mg}, \mathrm{mp} 85-86{ }^{\circ} \mathrm{C}$ (decomp.) $\left(\mathrm{CH}_{2} \mathrm{Cl}_{2}\right)$, IR: 3440s (br.), 2935m, 2830vs (br.), 2722vs (br.), 2646vs (br.), 2537s (br.), 1687m, 1404m, 1288m, 1267m, 1239m, 1210vs, 1188m, $1161 \mathrm{~m}, 1085 \mathrm{~s}, 957 \mathrm{~s} .{ }^{1} \mathrm{H}$ NMR (600 MHz, CD $\left.3 \mathrm{OD}\right), 8.45-8.44$ (m, 2 arom. H), 7.60-7.59 (m, 3 arom. H), 2.45 and $2.23(2 \mathrm{~s}, 6 \mathrm{H}, 2 \mathrm{Me}) .{ }^{13} \mathrm{C} \mathrm{NMR}\left(150 \mathrm{MHz}, \mathrm{CD}_{3} \mathrm{OD}\right), 147.4,143.5,128.4$ and $122.4(4 \mathrm{~s}, \mathrm{C}(\mathrm{Ph}), \mathrm{C}(2), \mathrm{C}(4), \mathrm{C}(5)), 131.0,128.7$ and $125.2(3 \mathrm{~d}, 5$ arom. $\mathrm{CH}), 121.1$ (q, ${ }^{1} J_{\mathrm{C}-\mathrm{F}}=$ 289.5, 2 $\left.\mathrm{CF}_{3}\right), 92.7$ (hept, $\left.{ }^{2} J_{\mathrm{C}-\mathrm{F}}=31.5, C\left(\mathrm{CF}_{3}\right)_{2}\right), 9.2$ and $4.7(2 \mathrm{q}, 2 \mathrm{Me}) .{ }^{19} \mathrm{~F} \mathrm{NMR}\left(\mathrm{CD}_{3} \mathrm{OD}\right),-$ $81.4\left(\mathrm{~s}, 2 \mathrm{CF}_{3}\right)$. Anal. Calcd for $\mathrm{C}_{11} \mathrm{H}_{11} \mathrm{NO}_{2} \cdot \mathrm{C}_{3} \mathrm{H}_{2} \mathrm{~F}_{6} \mathrm{O}_{2}$ (373.26): C, 45.05; H, 3.51; N, 3.75\%, Found: C, 45.09; H, 3.41; N, 4.22\%.

Complex of 4,5-dimethyl-2-[ $p$-( $N, N$-dimethylamine)phenyl]oxazole 3-oxide with HFAH (6b). The product precipitates from mother liquor and was analyzed without purification. Colorless crystals, yield 66\%, $275 \mathrm{mg}, \mathrm{mp} 100-101{ }^{\circ} \mathrm{C}$ (decomp.) $\left(\mathrm{CH}_{2} \mathrm{Cl}_{2} / \mathrm{Et}_{2} \mathrm{O}\right)$, IR: 3444vs (br.), 2927s, 2657vs (br.), 2533s (br.), 1608s, 1521m, 1399m, 1378m, 1203vs, 1157m, 1087m, 958m. ${ }^{1} \mathrm{H}$ NMR (600 MHz, $\left.\mathrm{CD}_{3} \mathrm{OD}\right), 8.28-8.25$ (m, 2 arom. H), 6.87-6.85 (m, 2 arom. H), 3.08 (s, 6H, $\left.\mathrm{NMe}_{2}\right), 2.38$ and 2.19 (2s, 6H, 2Me). ${ }^{13} \mathrm{C} \mathrm{NMR}\left(150 \mathrm{MHz}, \mathrm{CD}_{3} \mathrm{OD}\right), 152.4,148.9,141.3$, 127.1 and $109.2(5 \mathrm{~s}, 2 \mathrm{C}(\mathrm{Ph}), \mathrm{C}(2), \mathrm{C}(4), \mathrm{C}(5)), 127.0$ and $111.1(2 \mathrm{~d}, 4$ arom. $\mathrm{CH}), 121.2\left(\mathrm{q},{ }^{1} J_{\mathrm{C}-\mathrm{F}}\right.$ $\left.=288.0,2 \mathrm{CF}_{3}\right), 92.7\left(\right.$ hept $\left.,{ }^{2} J_{\mathrm{C}-\mathrm{F}}=31.5, C\left(\mathrm{CF}_{3}\right)_{2}\right), 38.7\left(\mathrm{q}, 2 \mathrm{CH}_{3},-\mathrm{NMe}_{2}\right), 9.1$ and $4.8(2 \mathrm{q}, 2 \mathrm{Me})$.

${ }^{19} \mathrm{~F}$ NMR $\left(\mathrm{CD}_{3} \mathrm{OD}\right),-81.3\left(\mathrm{~s}, 2 \mathrm{CF}_{3}\right)$.

\section{Decomposition of complexes (4) leading to imidazol-2-ones (3)}

A sample of a salt $4(1.0 \mathrm{mmol})$ was heated $+10{ }^{\circ} \mathrm{C}$ above its melting point for $10 \mathrm{~min}$. Resulting material was purified by flash chromatography $\left(\mathrm{SiO}_{2}, \mathrm{CHCl}_{3} / \mathrm{AcOEt} 2: 1\right)$ and recrystallized.

1-Cyclohexyl-1,3-dihydro-4,5-diphenyl-2H-imidazol-2-one (3h). Colorless crystals, yield

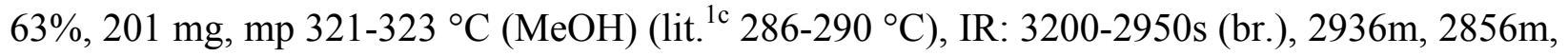
$1674 \mathrm{vs}, 1603 \mathrm{~m}, 1507 \mathrm{~m}, 1451 \mathrm{~m}, 1375 \mathrm{~m}, 1215 \mathrm{~m} .{ }^{1} \mathrm{H}$ NMR (600 MHz, $\left.\mathrm{CDCl}_{3}\right), 9.36$ (br s, $1 \mathrm{H}$, 
NH), 7.46-7.44 (m, 3 arom. H), 7.33-7.31 (m, 2 arom. H), 7.19-7.08 (m, 5 arom. H), 3.52-3.48 (m, 1H, cHex), 1.82-1.54 (m, 6H, cHex), 1.27-1.09 (m, 4H, $c$ Hex).

1,3-Dihydro-1,5-dimethyl-4-phenyl-2H-imidazol-2-one (3i). Colorless crystals, yield 72\%, $136 \mathrm{mg}, \mathrm{mp} 248-251{ }^{\circ} \mathrm{C}(\mathrm{MeOH})$ (lit. $\left.{ }^{1 \mathrm{c}} 246-251{ }^{\circ} \mathrm{C}\right)$, IR: 3200-2900s (br.), 2858m, 1675vs, $1603 \mathrm{~m}, 1503 \mathrm{~m}, 1460 \mathrm{~m}, 1435 \mathrm{~m}, 1397 \mathrm{~m}, 1384 \mathrm{~m} .{ }^{1} \mathrm{H}$ NMR (600 MHz, $\left.\mathrm{CDCl}_{3}\right), 9.37$ (br. s, $1 \mathrm{H}$, $\mathrm{NH}), 7.41-7.36$ (m, 5 arom. H), 3.26 and 2.24 (2s, 6H, 2Me).

1,3-Dihydro-5-methyl-4-phenyl-1-(prop-2-enyl)-2H-imidazol-2-one (3j). Colorless needles, yield 49\%, $105 \mathrm{mg}, \mathrm{mp}$ 187-189 ${ }^{\circ} \mathrm{C}\left(\mathrm{Et}_{2} \mathrm{O}\right)$ (lit. $\left.{ }^{1 \mathrm{~d}} 183-184{ }^{\circ} \mathrm{C}\right)$, IR: 3150-2280s (br.), 1694vs, $1639 \mathrm{~m}, 1502 \mathrm{~m}, 1458 \mathrm{~m}, 1429 \mathrm{~m}, 1408 \mathrm{~m}, 1345 \mathrm{~m} .{ }^{1} \mathrm{H}$ NMR (600 MHz, $\left.\mathrm{CDCl}_{3}\right), 9.69$ (br. s, $1 \mathrm{H}$, $\mathrm{NH}), 7.41-7.24$ (m, 5 arom. $\mathrm{H}), 5.95-5.89(\mathrm{~m}, 1 \mathrm{H},-\mathrm{CH}=), 5.20-5.12\left(\mathrm{~m}, 2 \mathrm{H},=\mathrm{CH}_{2}\right), 4.34-4.33$ (m, 2H, $\left.\mathrm{CH}_{2}\right), 2.22$ (s, 3H, Me).

Reaction of complex (4f) with 2,2,4,4-tetramethylcyclobutane-1,3-dithione - a test experiment. To the solution of $\mathbf{4 f}(110 \mathrm{mg}, 0.3 \mathrm{mmol})$ in $2 \mathrm{ml} \mathrm{CHCl}_{3}$ a solution of dithione (27 $\mathrm{mg}, 0.16 \mathrm{mmol}$ ) in $1 \mathrm{ml}$ of the same solvent was added in one portion at room temperature. The progress of the reaction was monitored by TLC (silica gel, ethyl acetate) and the complete conversion of complex $\mathbf{4 f}$ was established after 3 days.

For comparison, analogous reaction of $\mathbf{1 f}$ with dithione was run and monitored at the same conditions. In this case, starting material was completely converted into imidazole-2-thione after ca. $30 \mathrm{~min}$.

\section{Acknowledgements}

The authors thank the Polish Ministry for Science and Higher Education for financial support (Grant \# N N204 130335).

\section{References}

*Imidazol-2-ones are characterized by a strong IR absorption of the $\mathrm{C}=\mathrm{O}$ bond localized in the region between 1670 and $1690 \mathrm{~cm}^{-1}$.

1. (a) Mlostoń, G.; Gendek, T.; Heimgartner, H. Helv Chim Acta 1998, 81, 1585. (b) Mlostoń, G.; Gendek, T.; Heimgartner, H. Tetrahedron 2000, 56, 5405. (c) Mlostoń, G.; Celeda, M.; Prakash, G. K. S.; Olah, G. A.; Heimgartner, H. Helv. Chem. Acta 2000, 83, 728. (d) Mlostoń, G.; Jasiński, M.; Linden, A.; Heimgartner, H. Helv. Chim. Acta 2006, 89, 1304. (e) Mlostoń, G.; Romański, J.; Jasiński, M.; Heimgartner, H. Tetrahedron: Asymmetry 2009, 20, 1073. (f) Jasiński, M.; Mlostoń, G.; Heimgartner, H. J. Heterocycl. Chem. 2010, 47, 1287. 
2. (a) Jasiński, M.; Mlostoń, G.; Mucha, P.; Linden, A.; Heimgartner, H. Helv. Chim. Acta 2007, 90, 1765. (b) Jasiński, M.; Mlostoń, G.; Linden, A.; Heimgartner, H. Helv. Chim. Acta 2008, 91, 1916. (c) Jasiński, M.; Mlostoń, G. Coll. Czech. Chem. Commun. 2010, 75, 871.

3. (a) Mucha, P.; Mlostoń, G.; Jasiński, M.; Linden, A.; Heimgartner, H. Tetrahedron: Asymmetry 2008, 19, 1600. (b) Kwiatkowski, P.; Mucha, P.; Mlostoń, G.; Jurczak, J. Synlett 2009, 11, 1757.

4. (a) Ferguson, I. J.; Schofield, K. J. Chem. Soc., Perkin Trans. 1 1975, 275. (b) Bartnik, R.; Hahn, W.; Mlostoń, G. Roczniki Chem. 1977, 51, 49 (CA: 1977, 87, 53155). (c) Cerecetto, H.; Gerpe, A.; Gonzáles, H.; Fernandez Sainz, Y.; Piro, O. E. Synthesis 2004, 2678. (d) Alcázar, J.; Begtrup, M.; de la Hoz, A. J. Chem. Soc., Perkin Trans. 1 1995, 2467. (e) Alcázar, J.; Begtrup, M.; de la Hoz, A. Heterocycles 1996, 43, 1465.

5. (a) Arduengo III, A. J.; Harlow, R. L.; Kline, M. J. Am. Chem. Soc. 1991, 113, 361. (b) Arduengo III, A. J.; Kline, M.; Calabrese, J. C.; Davidson, F. J. Am. Chem. Soc. 1991, 113, 9704. (c) Herrmann, W. A.; Angew. Chem. Int. Ed. 2002, 41, 1290. (d) Bourissou, D.; Guerret, O.; Gabbaï, F. P.; Bertrand, G. Chem. Rev. 2000, 100, 39.

6. Loska, R.; Mąkosza, M. Chem. Eur. J. 2008, 14, 2577.

7. (a) Moreno-Fuquen, R.; de Almeida Santos, R. H.; do Prado Gambardella, M. T. Acta Cryst. 1997, C53, 1634. (b) Moreno-Fuquen, R.; do Prado Gambardella, M. T.; Valderrama-N, J. Acta Cryst. 1998, C54, 515.

8. Weintraub, P. M. J. Med. Chem. 1972, 15, 419.

9. (a) Aldrich, P. E.; Hermann, E. C.; Meier, W. E.; Paulshock, M.; Prichard, W. W.; Snyder, J. A.; Watts, J. C. J. Med. Chem. 1971, 14, 535. (b) Boudou, C.; Bergès, M.; Sagnes, C.; Spoková-de Oliveira Santos, J.; Perrio, S.; Metzner, P. J. Org. Chem. 2007, 72, 5403. (c) Martìnez-Aguilera, L. M. R.; Cadenas-Pliego, G.; Contreras, R.; Flores-Parra, A. Tetrahedron: Asymmetry 1995, 6, 1585.

10. Grigoriev J. A. Nitrones: Novel Strategies in Synthesis, in Nitrile Oxides, Nitrones, and Nitronates in Organic Synthesis; Novel Strategies in Synthesis, H. Feuer, Ed., Wiley and Sons, New Jersey 2008.

11. Hine, J.; Flachskam, N. W. J. Org. Chem. 1977, 42, 1979.

12. Laufer, S.; Wagner, G.; Kotschenreuter, D. Angew. Chem. Int. Ed. 2002, 41, 2290. 